\title{
СТАН КОНТРОЛЮ ЗА ДІЯЛЬНІСТЮ АПАРАТУ СУДУ В УМОВАХ РЕФОРМУВАННЯ СУДОВОЇ СИСТЕМИ
}

Шум M. C.

Метою статті $\epsilon$ теоретико-правовий аналіз сучасних підходів до стану контролю за ефективністю діяльності aпарату суду та визначення пропозицій щодо їх удосконалення. У статmі досліджено сучасний стан контролю за діяльністю апарату суду в умовах реформування судовоі системи. Проаналізовано етимологічне тлумачення та наукові погляди на поняття контролю. Узагальнені зазначені напрацювання на основі наукових праць, у межах яких розглядається стан контролю за діяльністю апарату суду. Враховуючи законодавство про судоустрій і наукові напрацювання, викладено авторське бачення ознак, поняття й видів контролю за діяльністю апарату суду. Поняття «контроль за діяльністю апарату суду» визначено як діяльність загальних і спеціальних органів і їх посадових осіб, які наділенні специфічними повноваженнями на здійснення контрольної діяльності та реалізують контроль у визначених відповідно до законодавства й посадових інструкцій формах, що виражається в спостереженні за дотриманням працівниками апарату суду чинного законодавства, перевірці відповідності виконання працівниками покладених на них повноважень, а також фіксації випадків учинених працівниками апарату суду правопорушень чи фактів здійснення позитивних ініціатив і застосування до них певних санкцій або заохочень відповідно, а також припинення, усунення й запобігання вчиненню подібних неправомірних дій у майбутньому з метою удосконалення рівня ефективності функціонування апарату суду і підвищення якості виконання працівниками визначених завдань. Зроблено висновок, що контроль за діяльністю апарату суду $є$ малодослідженим явищем. Національне законодавство вельми загально й розпорошено визначає основні положення, пов'язані зі здійсненням контролю за діяльністю апарату суду. Необхідність законодавчого закріплення досліджуваного категоріального апарату зумовлено низкою причин, серед яких основними є захист працівників апарату суду від можливих зловживань з боку контрольних органів і визначення конкретності, а саме форми, виду, змісту, кінцевої мети суб'єктів здійснення контролю.

Ключові слова: контроль, нагляд, функція, управління, види, апарат суду, судоустрій, суд.

Целью статьи является теоретико-правовой анализ современных подходов к состоянию контроля эффективности деятельности аппарата суда и определение предложений по их усовершенствованию. $\mathrm{B}$ статье исследовано современное состояние контроля за деятельностью апnарата суда в условиях реформирования судебной системы. Проанализированы этимологическое толкование и научные взгляды на понятие контроля. Обобщены указанные нара ботки на основе научных трудов, в пределах которых рассматривается состояние контроля за деятельность аппа рата суда. С учетом законодательства о судоустройстве и научных наработок определено авторское видение признаков, понятие и виды контроля за деятельностью аппарата суда. Oпределено авторское видение определения понятия «контроль за деятельностью аппарата суда» как деятельности общих и специальных органов и их должностных лиц, наделении специфическими полномочиями на осуществле- ние контрольной деятельности и реализации контроля в определенных соответствии с законодательством и должностными инструкциями формах, что выражается в наблюдении за соблюдением работниками аппарата суда действующего законодательства, проверке соответствия выполнения работниками возложенных на них полномочий, а также фиксации случаев, совершенных работниками aпnарата суда правонарушений или фактов осуществления положительных инициатив и применения к ним определенных санкций или поощрений соответственно, a также прекращение, устранение и предупреждение совершения подобных неправомерных действий в будущем с целью повышения уровня эффективности функционирования аппарата суда и качества выполнения работниками определенных задач. Сделан вывод, что контроль деятельности annapama суда является малоисследованным явлением. Национальное законодательство достаточно обобщенно и распыленно определяет основные положения, связанные с осуществлением контроля за деятельностью annарата суда. Необходимость законодательного закрепления изучаемого категориального аппарата обусловлена рядом причин, среди которых основными являются защита работников аппарата суда от возможных злоупотреблений со стороны контролирующих органов и определение конкретности, а именно формы, вида, содержания, конечной цели, субъектов осуществления контроля.

Ключевые слова: контроль, надзор, функция, управление, виды, аппарат суда, судоустройство, суд.

The purpose of the article is a theoretical and legal analysis of modern approaches to the state of control over the effectiveness of the activity of the court apparatus and to determine proposals for their improvement. The article examines the current state of control over the activities of the court apparatus in the context of reforming the judicial system. The etymological interpretation and scientific views on the concept of control are analyzed. Summarizing these developments, attention is drawn to scientific work within which the state of control over the activities of the court apparatus is considered. Considering the legislation on the judicial system and scientific developments, the author's vision of features, the concept and types of control over the activities of the court apparatus are defined. The author's vision of defining the concept of "control over the activity of the court apparatus" as an activity of general and special bodies and their officials, which are empowered with specific powers to carry out control activities, and exercise control in the forms determined in accordance with the legislation and official instructions, expressed in the observation of the observance by employees of the court apparatus of the current legislation, verification of compliance by employees with the powers assigned to them, as well as fixing cases nenyh offenses court staff or the fact of positive initiatives and application of certain sanctions or rewards accordingly and suspension, eliminate and prevent the occurrence of similar misconduct in the future to improve the level of efficiency of the court system and improve the quality of implementation of designated tasks. It is concluded 
that control over the activity of the court apparatus is a poorly researched phenomenon. The national legislation is quite general and scattered to define the main provisions related to the control of the activity of the court apparatus. The necessity of legislative consolidation of the investigated categorical apparatus is caused by a number of reasons, among which the main, first of all, is to protect the employees of the court apparatus from possible abuses by the controlling bodies and to determine the specificity, namely the form, type, content, ultimate purpose, subjects of exercising control.

Key words: control, supervision, function, management, types, court apparatus, judicial system, court.

Постановка проблеми. Суди в Україні у своїй діяльності потребують організаційно-технічної, інформаційно-аналітичної, кадрової й документальної допомоги, яку надає апарат суду. Він не бере участі в здійсненні правосуддя безпосередньо, однак відіграє важливу роль, оскільки забезпечує необхідні умови для його нормальної реалізації. Цілком очевидно, що рівень ефективності та якість виконання апаратом суду своїх функцій прямо впливає на правосудну діяльність суду. Отже, під час здійснення судами заходів організаційно-правового характеру важливу роль відіграють питання контролю, який хоч i опосередковано, але бере учать у реалізації правосуддя.

Контролю за діяльністю апарату суду дає змогу визначити рівень якості виконання покладених на суд завдань і функцій. У теорії держави й права контроль $\epsilon$ одним із провідних напрямів управлінської діяльності. Мета контролю полягає в сприянні своєчасному й правильному виконанню завдань, рішень, доручень керівництва. Таким чином, контроль дає змогу отримати необхідну інформацію для оцінки ефективності діяльності апарату суду.

Аналіз останніх досліджень i публікацій. Дослідженням стану контролю за діяльністю апарату суду в сучасних умовах у межах наукових праць займалися багато вчених. Серед них варто виокремити В.Б. Авер'янова, О.Ф. Андрійко, О.М. Бандурка, Ю.П. Битяка, Ф.Ф. Бутинець, І.П. Голосніченко, О.І. Безпалову, О.Ю. Дрозда, О.В. Джафарову, С.В. Пєткова, Є.Ю. Соболя, С.В. Ківалова, Л.В. Коваль, П.М. Рабиновича, В.І. Ремньова, В.Я. Тація, Ю.О. Тихомирова, М.М. Тищенко, Ю.М. Тодика, Р.Й. Халфіна, В.В. Цвєткова. Проте на сьогодні чимало питань залишаються невирішеними з позиції законодавчого врегулювання.

Метою статті $\epsilon$ теоретико-правовий аналіз сучасних підходів до стану контролю за ефективністю діяльності апарату суду й визначення пропозицій щодо їх удосконалення.

Виклад основного матеріалу дослідження. Контроль за діяльністю апарату суду відіграє важливу роль в роботі суду, вони $\epsilon$ тісно пов'язаними між собою. Але варто визнати, що у сфері контролю за діяльністю апарату суду $\epsilon$ низка проблем. Проаналізувавши наукову літературу й значну частину нормативно-правових актів, можна зробити висновок, що на сьогодні не існує чіткого уявлення про сутність контролю за діяльністю апарату суду, не визначена правова регламентація здійснення контролю в цій сфері, потребують уточнення коло суб'єктів, які здійснюють контроль за діяльністю апарату суду, необхідним $€$ уточнення форм проведення оцінювання ефективності діяльності апарату суду. Зважаючи на вищевикладене, очевидною постає нагальна потреба в дослідженні теоретичних і правових питань, пов'язаних з контролем і формами оцінювання ефективності діяльності апарату суду в сучасних умовах.

Окрім загальнотеоретичних аспектів здійснення контролю, науковцями досліджувалися також питання контролю в окремих сферах, зокрема у сфері виконавчої влади, судового, фінансового та інших видів контролю. Безпосередньо проблемі контролю за діяльністю апарату суду присвячено невелику кількість праць. Однією з найбільш вагомих і розгорнутих є робота українського вченого П.П. Порощука [1, с. 2], який глибоко дослідив адміністративно-правові засади здійснення контролю за діяльністю апарату суду.

Проаналізувавши низку праць у галузі юриспруденції, розуміємо, що контроль $є$ частим предметом наукових пошуків, однак недостатньо дослідженим в обраній нами тематиці, а форми оцінювання ефективності діяльності апарату суду досліджувалися лише частково. Така ситуація свідчить про актуальність і необхідність поглибленого вивчення цієї проблеми.

Термін «контроль» $є$ часто вживаним як у практичній діяльності органів державної влади, так і в наукових роботах. Найчастіше «контроль» означає «перевірка», «фіксація», «ревізія», «спостереження» тощо. Для більш глибокого й повного розуміння поняття «контроль» варто провести дослідження в різних галузях наукової площини.

Вивчаючи це питання, варто почати з тлумачення слова «контроль». У Великий тлумачний словник сучасної української мови під редакцією В.Т. Бусела визначає «контроль», як перевірку відповідності контрольованого об'єкта встановленим вимогам [2, с. 569]. Також термін «контроль» у тлумачній літературі визначається як «перевірка», «облік діяльності кого-, чого-небудь», «нагляд за кимось, чимось» [3, с. 271]. Слід відзначити, влучно підкреслено: здійснюється перевірка саме встановлених вимог. Таке уточнення $\epsilon$ достатньо характерним елементом, якщо говорити про юридичне спрямування. Слідуючи цій логіці, ми вже підсвідомо розуміємо, що $є$ певні стандарти, нормативи, які потребують контролю виконання. Тобто попри те, що визначення $\epsilon$ загальним, йому все ж притаманна спеціальна риса правового характеру.

Тлумачний словник економіста визначає контроль так: 1) перевірка виконання завдань; 2) складова управління економічними об'єктами й процесами; 3) дії, пов'язані з перевіркою, контролем [4, с. 168].

Н.В. Синюгіна поєднує ці значення в одній дефініції. На їі думку, контроль - це функція управління, яка передбачає використання загальних і специфічних методів з метою встановлення відхилень об'єкта контролю від заданих параметрів [5, с. 76]. Цілком логічним $\epsilon$ визначення контролю як функції управління. Адже для менеджменту контроль $є$ рушійною силою для реалізації інших функцій. Як вже зазначалося, він призначений для проведення оцінки відповідності завданням, які має управління. А отже, ігнорування цієї функції може призвести до отримання інших результатів або невиконання поставлених завдань взагалі.

Якщо говорити про контроль у правовій сфері, варто звернутися до Юридичної енциклопедії за редакцією Ю.С. Шемшученка, де вказано, що контроль (франц. controle - перевірка, від старофранц. contrerole - список, що має дублікат для перевірки) - це перевірка 
виконання законів, рішень тощо. $Є$ однією з найважливіших функцій державного управління [6].

У своїй праці С.В. Ківалов визначає контроль як функцію, вважаючи основними його ознаками такі: 1) державно-владний характер; 2) законність; 3) об'єктивність; 4) всебічність; 5) забезпечення можливості втручання контролюючого суб'єкта в діяльність контрольованого тощо [7, с. 74].

Підсумовуючи наведені погляди різних науковців, можна виокремити такі притаманні контролю ознаки: 1) контроль $\epsilon$ управлінською функцією; 2) відповідає принципу законності, здійснюється лише в межах, визначених чинним законодавством; 3) здійснюється 3 метою перевірки виконання встановлених стандартів (вимог); 4) наявний контролюючий орган наділений владними повноваженнями здійснювати діяльність, пов'язану з контролем; 5) контролюючий орган $\epsilon$ неупередженим і незалежним під час проведення контролю відносно суб'єкта контролю; 6) має широкий спектр методів проведення контролю, від заохочення до санкцій; 7) основна мета - досягнення найбільш бажаного результату від поставлених завдань.

Враховуючи вищесказане, можна зробити висновок, що незалежно від сфери діяльності сутність контролю полягає в спостережені/обліку/перевірці діяльності когось або чогось. Метою контролю $є$ своєчасне виявлення помилок у процесі управління та їх виправлення, а також ліквідація чинників, що їх спричинили. Такі дії спрямовані на запобігання зловживанням і забезпечення відповідності між поставленими цілями й фактичними діями контрольованих суб'єктів.

Залежно від різних підстав контроль може бути кількох видів. Зазвичай у наукових колах використовуються традиційні класифікації, які визнаються більшістю вчених, однак трапляються й авторські варіанти окремих науковців.

Так, О.М. Музичук поділяє на види контроль за такими критеріями: 1) залежно від суб'єктів, які його здійснюють (міжнародний, державний, самоврядний, громадський); 2) залежно від організаційно-штатного зв'язку (зовнішній, альтернативний (або змішаний), внутрішній); 3) за часом здійснення (постійний, тимчасовий); 4) залежно від стадій розгляду контрольного питання (попередній, поточний, подальший); 5) за відкритістю (гласний, негласний); 6) залежно від кола контрольованих видів діяльності (загальний, спеціальний) тощо [8, с. 100-102]. Такий поділ $є$ найбільш усталеним, здебільшого вже визначені види роздроблюють на підвиди або пропонуються відповідно до змін часу додаткові види до наявних критеріїв. Таким чином, класифікація $\epsilon$ теоретичним відображенням широкої палітри різноплановості й різноманітності, підтверджуючи невичерпність наявних у теорії видів.

В.Л. Синчук звертає увагу на те, що деякі класифікації $€$ неповними, оскільки не враховують суб'єктний та об'єктний склад, і пропонує розподіляти за такими критеріями: 1) за суб'єктами, уповноваженими здійснювати певний контроль (парламентський, президентський, контроль органів виконавчої влади, судовий); 2) за обсягом контрольних повноважень (загальний, спеціальний); 3) за правомірністю (правомірний і неправомірний); 4) за характером здійснення контролю (прямий і непрямий); 5) за часом проведення контролю (ретроспективний, поточний і перспективний); 6) за періодом здійснення (постійний, систематичний, одноразовий); 7) за типом субординації в процесі здійснення контролю (внутрішній і зовнішній); 8) за обсягом дослідження об'єкта контролю (суцільний і частковий); 9) за сферою, складовими діяльності органів прокуратури (контроль виконання, контроль нормотворчості, контроль за дотриманням дисципліни, фінансовий (банківський, податковий, бюджетний тощо) контроль, статистичний контроль тощо); 10) залежно від кількості суб'єктів контролю (колективний і одноосібний); 11) за формами здійснення перевірка, ревізія, моніторинг тощо; 12) залежно від мети контролю: (запобіжний, активний і пасивний); 13) за ступенем значущості (формальний, звичайний і актуальний); 14) залежно від плановості контрольних заходів (плановий, позаплановий); 15) за природою реалізації (фактичний (реальний), документальний) [9, с. 85-86]. Вважаємо, така класифікація дійсно є максимально розгорнутою й багатоаспектною. Однак не поділяємо думку автора з приводу поділу на правомірний і неправомірний види. Цілком очевидно, що поняття «неправомірний» означає «має незаконний характер». Оскільки контроль має на меті перевірку відповідності встановленим правилам, то і здійснення контролю повинно ґрунтуватися на визначених законодавством нормах. Таким чином, неправомірно проведений контроль не відповідатиме необхідним вимогам посадових інструкцій контролюючого органу й чинному законодавству i, відповідно до аналогії закону не маючи юридичної сили, не може вважатися таким, що був проведений. Вважаємо, що виокремлення неправомірного контролю $€$ некоректним і недоцільним з погляду змісту мети проведення контролю.

Слід звернути увагу, що під час здійснення будьякого контролю зазвичай він буває одночасно декількох видів. Наприклад, правомірний судовий поточний постійний контроль за дотриманням дисципліни під час судового засідання чи одноособова позапланова внутрішня перевірка з метою запобігання виникненню зловживань під час виконання службових завдань апаратом суду.

Що стосується законодавства, то слід наголосити на наявності визначених класифікацій у спеціальних нормативно-правових актах. Так, ст. 2 Закону України «Про основні засади державного нагляду (контролю) у сфері господарської діяльності» від 5 квітня 2007 р. № 877-V містить поділ видів контролю залежно від предмета (напряму здійснення господарської діяльності) на такі види: валютний контроль, податковий контроль, митний контроль, державний експортний контроль, контроль за дотриманням бюджетного законодавства, банківський нагляд, контроль за дотриманням законодавства про захист економічної конкуренції, державний контроль у галузі телебачення й радіомовлення тощо [10], а також залежно від плановості ст. ст. 5, 6 передбачають плановий і позаплановий контроль [11]. Аналогічний поділ за критерієм плановості містить і Наказ Фонду державного майна України Про затвердження Порядку здійснення контролю за виконанням умов договорів купівлі-продажу об'єктів приватизації органами приватизації від 18 жовтня 2018 р. № 1327 [12].

У Законі України «Про національну безпеку України» від 21 червня 2018 р. № 2469-VIII ст. 4 теж закріплено класифікацію, що містить два критерії: 1) залежно від суб'єкта (контроль, який здійснюється Президентом України, Верховною Радою України, Радою національної 
безпеки і оборони України, Кабінетом Міністрів України, органами виконавчої влади, органами місцевого самоврядування; судовий та громадський контроль); 2) залежно від предмету (контроль за змістом і станом реалізації стратегій, державних програм і планів у сферах національної безпеки й оборони, контроль за ефективністю використання ресурсів, контроль за станом готовності органів сектору безпеки й оборони до виконання завдань за призначенням у мирний час та в особливий період) [13].

Слід зазначити, що залежно від форми проведення в чинному законодавстві, зокрема ст. 19 Закону України «Про державний контроль за дотриманням законодавства про харчові продукти, корми, побічні продукти тваринного походження, здоров'я та благополуччя тварин» від 18 травня 2017 р. № 2042-VIII контроль поділяється на аудит, огляд, відбір зразків, лабораторне дослідження (випробовування), документальну перевірку, перевірку відповідності, фізичну перевірку [14]. Узагальнюючи визначені в законах класифікації, можна зробити висновки, що попри їх різне спрямування критерії для класифікації контролю здебільшого $\epsilon$ незмінними. Так, сталими $\epsilon$ такі підстави: 1) предмет перевірки; 2) плановість контрольних заходів; 3) суб'єкт, який здійснює перевірку; 4) форма проведення контролю. Таким чином, слід зазначити, що в діях законодавця простежується певна закономірність й узгодженість у визначенні контролю та його видів під час формування законодавчих актів. Відсутність універсально визначеної класифікації компенсує системний підхід законодавчих органів щодо формування нормативно правових актів, що сприяє кращому освоєнню даних категорій і формує загальне уявлення.

Говорячи безпосередньо про контроль за діяльністю апарату суду, варто звернутися до праці П.П. Порощука. У ній достатньо детально й найбільш розгорнуто надано визначення поняттю «контроль». Так, контроль за апаратом суду - це «специфічний різновид (прояв) управлінської діяльності компетентних органів і посадових осіб, що здійснюється на підставі, у порядку, формах і межах, визначених законодавством, і полягає в реалізації ними конкретних заходів щодо спостереження за належним виконанням працівниками судової установи та їі структурними ланками покладених на них завдань, функцій та обов'язків <...> 3 метою <...> виявлення та подолання недоліків (прогалин, відхилень) у діяльності судового апарату в цілому, так і його структурних ланках окремо, з метою підвищення рівня якості та ефективності виконання ними свого функціонального призначення» [15, с. 205].

Враховуючи наведені з різних галузей дефініції, а також спеціальне визначення, можна виокремити основні ознаки контролю за діяльністю апарату суду: 1) має державно-владний характер, тобто реалізується конкретними суб'єктами на яких покладено обов'язок здійснювати контрольну діяльність за апаратом суду чи його окремими структурними підрозділами; 2) відповідає принципу законності, суб'єкти діють на підставі та в межах закону; 3) об'єктивність, а саме неупереджене й незалежне ставлення контролюючого органу під час здійснення контролю за діяльністю апарату суду; 4) метою здійснення перевірки $\epsilon$ спостереження за станом відповідності діяльності апарату суду нормам законодавства, виявлення правопорушень і запобігання їм, а також підвищення ефективності і якості роботи.
Спеціальне законодавство, на жаль, не містить визначення контролю за діяльністю апарату суду й не повною мірою визначає види його здійснення, що на нашу думку $\epsilon$ значним недоліком і створює низку незручностей у практичній площині. Тому пропонуємо авторське бачення визначення поняття «контроль за діяльністю апарату суду» як діяльність загальних і спеціальних органів та їх посадових осіб, які наділенні специфічними повноваженнями на здійснення контрольної діяльності й реалізують контроль у визначених відповідно до законодавства й посадових інструкцій формах, що виражається в спостереженні за дотриманням працівниками апарату суду чинного законодавства, перевірці відповідності виконання працівниками покладених на них повноважень, а також фіксації випадків учинених працівниками апарату суду правопорушень чи фактів здійснення позитивних ініціатив і застосування до них певних санкцій або заохочень відповідно, а також припинення, усунення й запобігання вчиненню подібних неправомірних дій у майбутньому з метою підвищення рівня ефективності функціонування апарату суду й підвищення якості виконання працівниками визначених завдань.

3 вищенаведеного можна зробити висновок, що контроль за діяльністю апарату суду $є$ малодослідженим явищем. Національне законодавство доволі загально й розпорошено визначає основні положення, пов'язані зі здійсненням контролю за діяльністю апарату суду. Необхідність законодавчого закріплення досліджуваного категоріального апарату обумовлена низкою причин, серед яких основними $€$ захист працівників апарату суду від можливих зловживань з боку контролюючих органів і визначення конкретності, а саме форми, виду, змісту, кінцевої мети, суб'єктів здійснення контролю.

\section{Література}

1. Порощук П.П. Адміністративно-правові засади контролю за діяльністю апарату суду : автореф. дис. ... канд. юрид. наук : 12.00.07. Київ, 2015. 19 с.

2. Великий тлумачний словник сучасної української мови / Уклад. і голов. ред. В.Т. Бусел. Київ; Ірпінь : ВТФ «Перун», 2005. 1728 с.

3. Словник української мови : в 11 т. / за ред. І.К. Білодіда ; Інститут мовознавства АН УРСР. Київ : Наукова думка, 1970-1980. Т. 4.

4. Гончаров С.М., Кушнір Н.Б. Тлумачний словник економіста / за ред. проф. С.М. Гончарова. Київ : Центр учбової літератури, 2009. 264 с.

5. Синюгіна Н.В. Дискусійні питання визначення понять «контроль» і «ревізія». / Н.В. Синюгіна, Г.В. Яблонська. Економіка: реалії часу. 2011. № 1(1). С. 75-80.

6. Шемшученко Ю.С. Юридична енциклопедія : в 6 т. / відп. ред. Ю.С. Шемшученко. Київ : Українська енциклопедія, 1998. URL: https://leksika.com.ua/10530412/legal/kontrol.

7. Ківалов С.В. Адміністративне право : навчальнометодичний посібник / С.В. Ківалов та ін. Одеса : Фенікс, 2019. 136 с.

8. Музичук О.М. Види та форми контролю за діяльністю міліції. Вісник Харківського національного університету внутрішніх справ. 2010. № 2. С. 98-105.

9. Синчук В.Л. Види державного контролю за діяльністю органів прокуратури. Європейські перспективи. 2014. № 7 C. 84-89.

10. Про основні засади державного нагляду (контролю) у сфері господарської діяльності : Закон України від 5 квітня 2007 р. № 877-V. База даних «Законодавство України». URL: https://zakon.rada.gov.ua/laws/show/877-16. 


\section{Правове забезпечення адміністративної реформи}

11. Про основні засади державного нагляду (контролю) у сфері господарської діяльності : Закон України від 5 квітня 2007 р. № 877-V. База даних «Законодавство України». URL: https://zakon.rada.gov.ua/laws/show/877-16.

12. Про затвердження Порядку здійснення контролю за виконанням умов договорів купівлі-продажу об'єктів приватизації органами приватизації : Наказ Фонду державного майна України від 18 жовтня 2018 р. № 1327. База даних «Законодавство України». URL: https: //zakon.rada.gov.ua/ laws/show/z1349-18.

13. Про національну безпеку України : Закон України від 21 червня 2018 р. № 2469-VIII. База даних «Законодавство України». URL: https://zakon.rada.gov.ua/laws/ show/2469-19.
14. Про державний контроль за дотриманням законодавства про харчові продукти, корми, побічні продукти тваринного походження, здоров'я та благополуччя тварин : Закон України від 18 травня 2017 р. № 2042-VIII. База даних «Законодавство України». URL: https: / /zakon.rada.gov.ua/laws/show/2042-19.

15. Порощук П.П. Поняття та значення контролю за діяльністю апарату суду / П.П. Порощук. Науковий вісник Академії муніципального управління. Серія «Право». 2015. № 1. С. 200-208.

Шум M. C., здобувач

Науково-дослідного інституту публічного права 